\title{
35. NOBLE METAL ABUNDANCES IN BACKARC BASIN BASALTS (LAU BASIN, SOUTHWEST PACIFIC) ${ }^{1}$
}

\author{
Peter A. Cawood ${ }^{2}$ and Brian J. Fryer ${ }^{2}$
}

\begin{abstract}
Ocean Drilling Program Leg 135 backarc basin lavas are characterized by anomalously high Au contents (1.0-11.4 ppb) and strongly fractionated relative platinum group element (PGE) abundances ( $\mathrm{Pd} / \mathrm{Ir}$ ratio, approximately 100$)$. The $\mathrm{Rh}$ and Ir contents are very low, ranging from below detection (approximately $0.02 \mathrm{ppb}$ ) to $0.08 \mathrm{ppb}$. The $\mathrm{Pd}$ and $\mathrm{Pt}$ contents range from $\leq 0.3$ to 4 $\mathrm{ppb}$. Rh, Pd, and Pt values are consistently and significantly higher in Site 836 and 839 samples relative to those from Sites 834 and 835. Major, trace, and rare earth element (REE) data suggest Sites 836 and 839 have a more pronounced arc signature than Sites 834 and 835. No correlation exists between noble metal abundance and indices of alteration or fractionation (e.g., loss on

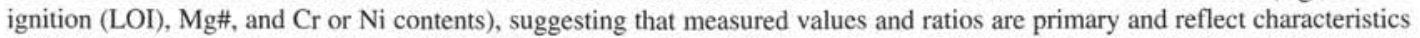
of the mantle source. The evaluation of Leg 135 noble metal data with respect to potential mantle-source components is hindered by the lack of data on magmas derived from such sources. However, analyses of the limited available data for the different magma types suggest that the characteristic enrichment of Leg 135 lavas in $\mathrm{Au}$, relative to $\mathrm{Pd}$ and $\mathrm{Cu}$, cannot be derived solely from simple MORB-type or ocean-island-type mantle, or mantle depleted by a previous melt extraction event. The Au-enriched signature of the Lau basin lavas could, however, be produced through the addition of a sedimentary component from the downgoing slab. Separation of Au from the PGE occurs within oceanic hydrothermal systems and gold values of the resultant precipitates are 2-3 orders of magnitude higher than other oceanic crustal components. Even small additions of this component from the downgoing oceanic crust to a supra-subduction zone mantle melt could account for the high mean Au/Pd ratios of the Leg 135 samples (Sites 834 and $835, \mathrm{Au} / \mathrm{Pd}=5.04$; Sites 836 and $839, \mathrm{Au} / \mathrm{Pd}=2.26$ ).
\end{abstract}

\section{INTRODUCTION}

The behavior of noble metals in igneous systems is poorly understood, and their extraction from an evolving magma has been related to a variety of processes, including the separation of PGE alloys (e.g., Keays, 1982), chromite (e.g., Agiorgitis and Wolf, 1978; Stockman and Hlava, 1984), an immiscible sulfide phase (e.g., Keays and Crocket, 1970; Naldrett et al., 1979; Barnes and Naldrett, 1985; Brugmann et al., 1987), and silicates, particularly olivine (Crocket, 1981; Brugmann et al., 1987; Fryer and Greenough, in press). This lack of understanding of their behavior reflects, in large part, the difficulty that has traditionally been associated with accurately determining the abundance of these elements in basaltic rocks where concentration levels are in the low- to sub-ppb range. The recent development of an analytical procedure using inductively coupled plasma-mass spectrometry (ICPMS; Jackson et al., 1990) allows routine analysis with mean instrumental detection limits in the sub-ppb range.

This paper outlines the concentration of the noble metals $\mathrm{Pt}, \mathrm{Pd}$, $\mathrm{Rh}, \mathrm{Ir}$, and Au in intraoceanic basaltic volcanic rocks of the Lau Basin, and evaluates their abundance with respect to the supra-subduction signature of the source magmas. The paper provides the first accurate data on noble metal concentrations in basalts and andesites from a modern backarc basin.

The Lau Basin forms part of the Tonga Arc system and is an ideal natural laboratory to study arc-backarc magmatism and the role of slab-controlled, crust-mantle interactions in governing noble metal abundances. The arc lies within a zone of complexly interacting microplates that have developed along the boundary between the Indo-Australian and Pacific plates. Plate boundaries within this region have evolved rapidly since the commencement of subduction in the Eocene, resulting in the progressive movement of the southwestern boundary of the Pacific Plate away from the Australian continent.

\footnotetext{
'Hawkins, J., Parson, L., Allan, J., et al., 1994. Proc, ODP, Sci. Results, 135: College Station, TX (Ocean Drilling Program).

${ }^{2}$ Centre for Earth Resources Research, Department of Earth Sciences, Memorial University of Newfoundland, St. John's, Newfoundland, Canada AIB 3X5.
}

The Tonga Arc records a relatively simple evolutionary picture. It is divisible into three tectonic elements. Extending westward from the Tonga Trench, these are (1) the active magmatic arc and forearc (Tonga Ridge), (2) the active backarc basin (Lau Ridge), and (3) the remnant arc (Lau Ridge). Before the initiation of seafloor spreading in the Lau Basin in the Miocene, the Lau and Tonga ridges constituted a single magmatic arc-forearc succession. The Lau Basin was the first backarc basin in which active seafloor spreading was documented (Karig, 1970), and it provides one of the best developed records of spreading processes. On Leg 135, a transact across the backarc investigated the process of crustal generation. Sites drilled range from Miocene-age basalts adjacent to the Lau Ridge, which were generated during the early stages of arc rifting and backarc basin development (Site 834), to approximately 1 Ma crust near the main spreading ridge for the Lau Basin (Site 836; Fig. 1).

The geochemical data available for the Lau Basin (e.g., Frenzel et al., 1990; Hawkins and Melchior, 1985; Jenner et al., 1987; Vallier et al., 1991; Volpe et al., 1988) indicate a range of compositional groups (and mantle-source components), from basaltic and andesitic rocks showing a strong arc (slab-derived) signature to basaltic rocks showing an N-MORB signature.

Recent cruises to the Valu Fa Ridge, the active spreading ridge within the southeastern position of the basin, have recognized active hydrothermal vents (Fouquet et al., 1990, 1991) and reported high concentrations of gold and visible gold in the sulfides (Herzig et al., in press). This is the first reported occurrence of visible, primary gold in sulfides from active seafloor vents. Establishing the noble metal concentrations within the Lau Basin basalts will allow a direct measure of gold levels in potential source basalts to the hydrothermal system.

\section{SAMPLE DESCRIPTION}

Samples for noble metal analysis were selected on the basis of petrographic descriptions and major and trace element analyses to provide a range of lithologic and compositional types. Samples analyzed from Sites $834,835,836$, and 839 include both phyric and aphyric basalts and hyaloclastic glass, and represent a wide composi- 


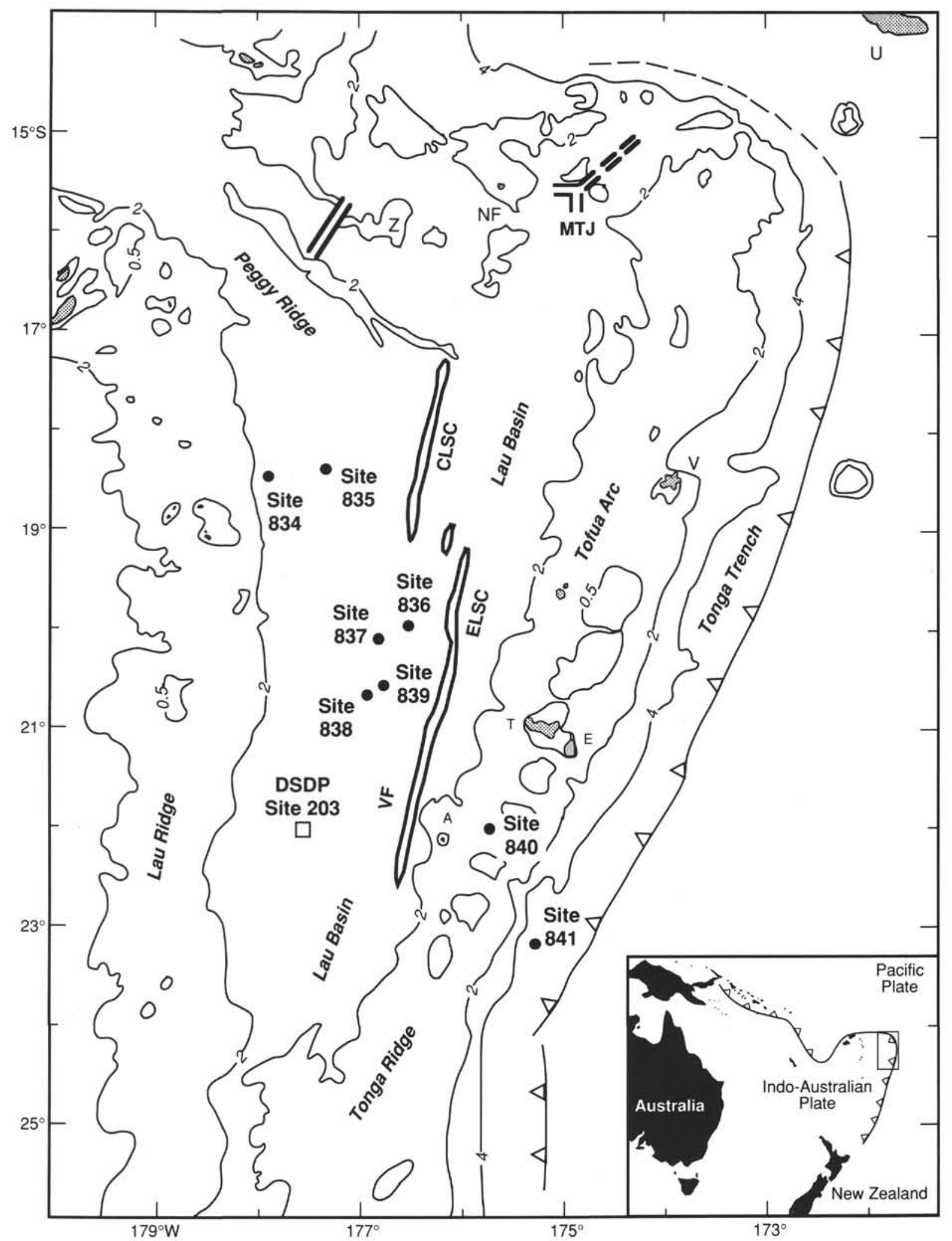

Figure 1. Distribution of major morphotectonic elements within the Tonga arc system and location of Leg 135 drill sites. 
tional range, on the basis of $\mathrm{Mg} \#$ and the $\mathrm{Cr}$ and $\mathrm{Ni}$ contents. The following sample descriptions were derived from shipboard data (Parsons, Hawkins, Allan, et al., 1992).

The locations of the Leg 135 drill sites $(834,835,836$, and 839) are given in Figure 1. Sites are located in the western and central Lau Basin, and all sites lie west of the youngest crust in the basin, which is forming at the Central (CLSC) and Eastern Lau (ELSC) Spreading Centers (Valu Fa). Sites 834 and 835 lie in small basins east of the Lau Ridge, which formed through rifting of older arc lithosphere, whereas Sites 836 and 839 lie close to the ELSC on true oceanic lithosphere related to organized backarc basin spreading.

Site 834 is located along the northwest margin of the Lau Basin, $100 \mathrm{~km}$ east of the axis of the Lau Ridge, and represents the oldest basin crust drilled on Leg 135. Igneous basement consists of a series of flows and sills. Seven samples from Units 2, 5, 6, and 7 were analyzed from this site and, on the basis of the biostratigraphy of sediments intercalated with the flows, range in age from lower Pliocene (4 Ma) to upper Miocene (6 Ma). Unit 2 is an aphyric, massive vesicular basalt with a groundmass of plagioclase, clinopyroxene, and minor interstitial magnetite and olivine. Unit 5 is a moderately altered aphyric, vesicular diabase. The groundmass is dominated by plagioclase microlites and larger clinopyroxene oikocrysts rich in plagioclase laths with lesser amounts of intergrown clinopyroxene. Magnetite is the main opaque oxide phase, but ilmenite, $\mathrm{Cr}$-spinels, and sulfide globules are also present in minor to trace amounts. Glassy, interstitial phases of the groundmass are altered to clay minerals. Unit 6 consists of aphyric to sparsely phyric, vesicular basalt. A glomeroporphyritic texture of plagioclase, clinopyroxene, and rare olivine is locally developed in a groundmass of plagioclase, clinopyroxene, olivine, magnetite, and a mesostasis that is typically altered to clays. Unit 7 is a highly phyric plagioclase basalt. At $76 \mathrm{~m}$, it is the thickest unit delineated at Site 834, and it consists of a series of pillowed flows. Vesicles are absent or extremely rare. Phenocrysts are glomeroporphyritic and consist mainly of euhedral plagioclase but also include minor olivine. Groundmass mineral phases in approximate decreasing order of abundance are plagioclase, clinopyroxene, magnetite, $\mathrm{Cr}$-spinel, and ilmenite. The mesostasis shows minor alteration to clays.

Site 835 is located $200 \mathrm{~km}$ east of the axis of the Lau Ridge. Igneous basement is constrained to be of late Pliocene age (3.4 Ma) on the basis of biostratigraphic data obtained from the immediately overlying sediments. A vesicular, plagioclase-clinopyroxene-olivine basalt is the only lithologic unit intersected at the site. Plagioclase is the main mineral phase followed by clinopyroxene. Olivine is a minor phase and magnetite is present in trace amounts. A continuous size gradation occurs from phenocryst to groundmass phases. The mesostasis is variably altered to clays.

Site 836 is situated $50 \mathrm{~km}$ west of the active ELSC (Valu Fa), which constitutes the main spreading center within the basin. Igneous basement at Site 836 may represent the oldest lithosphere generated at the ELSC. Five rock units were recognized in the basement, which on the basis of biostratigraphic data from intercalated sediments has a maximum age of middle Pleistocene $(<0.8 \mathrm{Ma})$. Units 1 and 2 are hyaloclastites and consist of vesicular, sparsely plagioclase phyric, glass-rich andesitic gravel. Samples analyzed from these units were repeatedly cleaned ultrasonically with distilled, deionized water before being crushed, and effectively represent clean glass samples. Unit 4 is divisible into two subunits of aphyric basalt separated by a thin sediment intercalation. It consists of plagioclase and clinopyroxene with minor olivine, magnetite, and interstitial mesostasis, variably altered to clays.

Site 839 is located some $75 \mathrm{~km}$ west of the ELSC (Valu Fa). Igneous basement was divided into eight lithologic units. Overlying sediments are of late Pliocene age ( $2 \mathrm{Ma}$ ). The single sample analyzed for noble metal abundances from this site occurs within Unit 1, a vesicular, sparsely to moderately phyric olivine basalt. The holocrystalline groundmass consists of plagioclase and clinopyroxene with minor olivine and magnetite.

\section{ANALYTICAL METHODS}

Gold, Pd, Pt, Rh, and Ir were determined by ICP-MS on $10 \%$ aqua regia solutions after NiS fire assay preconcentration of $10 \mathrm{~g}$ of rock powder. Complete method blanks, for this study, are $0.54,0.82,1.34$, 0.16 , and $0.05 \mathrm{ppb}$ (rock), respectively, for the above elements; these were subtracted from the raw data. The standard deviations of the method blanks. $(N=9)$ are $0.35,0.42,0.13,0.02$ and $0.02 \mathrm{ppb}$ (rock) for $\mathrm{Au}, \mathrm{Pd}, \mathrm{Pt}, \mathrm{Rh}$, and Ir, respectively; they provide the best estimate of the limits of detection for this method. It should be recognized that the complete method blanks include all sources of uncertainty such as reagent blanks, instrument memory, and backgrounds, and it is a much more reliable (and conservative) indicator of data reliability for analyses near "detection limits" than the more traditional 3 sigma $(\sigma)$ above background. The reader is referred to Jackson et al. (1990) for details of the complete procedure. Replicate analyses of the reference material SARM-7 have given 245, 1452, 3923, 227, and $77 \mathrm{ppb} \mathrm{Au}$, $\mathrm{Pd}, \mathrm{Pt}, \mathrm{Rh}$, and Ir, respectively, with relative standard deviations of $7 \%$ or better for all elements. All PGE values are within $10 \%$ of the certified concentrations. Replicate analyses of our in-house komatiite standard (BF-4) give relative deviations of $10 \%$ or better for concentrations (1-10 ppb) more closely approximating the rock compositions of this study.

\section{RESULTS}

Chemical data for the Leg 135 volcanic rocks are presented in Table 1. Major, trace, and rare earth element (REE) data are taken from Hawkins and Allan (this volume). The gold contents of all samples are surprisingly high, ranging from 1.0 to $11.4 \mathrm{ppb}$. Rhodium and Ir contents are very low, ranging from below detection (approximately $0.02 \mathrm{ppb}$ ) to $0.08 \mathrm{ppb}$. The Pd and Pt contents range from $\leq 0.3$ to $4 \mathrm{ppb}$, which is relatively high compared with other oceanic basalts (Table 2). Gold appears to be anomalously enriched relative to both the PGE and $\mathrm{Cu}$. Within this range of noble metal abundances, two groups are recognized. Sites 836 and 839 generally have higher abundances of Rh, Pd, and Pt than do Sites 834 and 835 . Gold and Ir values cover similar ranges at all sites.

In general terms, the major and trace element chemistry of the samples ranges from arc-like to more MORB-like in the sequence from Sites $839,836,835$, and 834, respectively (e.g., Fig. 2). The highest noble metal contents are found in the sites (836 and 839) that have the strongest arc signatures. At least for $\mathrm{Au}, \mathrm{Pd}$, and $\mathrm{Pt}$, noble metal abundances are not related to the degree of "fractionation" of the lavas, as expressed by Mg\# (Fig. 3). The bulk of the samples show

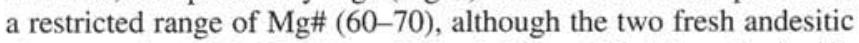
glass samples (Hole 836A) are distinctly lower (35). The only significant trend between noble metal content and major or trace elements is with $\mathrm{Cu}$ (Fig. 4). Lavas from Sites 839 and 836 have distinctly higher average $\mathrm{Cu}$ contents than those from Sites 835 and 834 (123 vs. $74 \mathrm{ppm}$ ), which parallels their much higher Pd and Pt contents (3.42 and $1.79 \mathrm{ppb}$ vs. 0.78 and $0.52 \mathrm{ppb}$, respectively). Although both groups have a similar overall range of Au values, mean $\mathrm{Au}$ abundances at Sites 836 and 839 are also much higher $(7.75 \mathrm{ppb})$ compared with Sites 834 and 835 (3.9 ppb). Within the high-Cu group, however, $\mathrm{Pd}$ and $\mathrm{Pd}+\mathrm{Pt}$ contents decrease with increasing $\mathrm{Cu}$ contents. This trend corresponds with increasing $\mathrm{SiO}_{2}$ contents. These relationships suggest that the compositional differences between the two groups cannot be ascribed to fractionation processes from similar primary magma sources.

Primitive mantle-normalized, noble metal distributions for the Lau Basin samples (Fig. 5) demonstrate the anomalous Au concentrations for all samples relative to the PGE and $\mathrm{Cu}$, as well as the strong fractionation within the PGE. In particular, Ir is strongly depleted relative to $\mathrm{Pd}$, with a mean $\mathrm{Pd} / \mathrm{Ir}$ ratio of approximately 90 for Sites 834 and 835 , and almost 100 for Sites 836 and 839 (Table 2). 
Table 1. Major, trace, and noble metal abundances for Leg 135 samples.

\begin{tabular}{|c|c|c|c|c|c|c|c|c|c|c|c|c|c|c|}
\hline Hole: & 834B & $834 B$ & 834B & 834B & 834B & 834B & 834B & $835 B$ & $836 \mathrm{~A}$ & $836 \mathrm{~A}$ & $836 \mathrm{~B}$ & $836 \mathrm{~B}$ & $836 \mathrm{~B}$ & 839B \\
\hline Section: & $8 R-1$ & $10 \mathrm{R}-1$ & $12 \mathrm{R}-3$ & $13 R-1$ & $18 \mathrm{R}-1$ & $28 \mathrm{R}-1$ & $33 \mathrm{R}-2$ & $7 \mathrm{R}-2$ & $3 \mathrm{H}-3$ & $3 \mathrm{H}-4$ & $3 R-1$ & $5 \mathrm{R}-2$ & $5 R-2$ & $15 \mathrm{R}-1$ \\
\hline XRF interval: & $105-109$ & $37-43$ & $66-71$ & & $26-35$ & $44-50$ & $111-115$ & $84-89$ & & $75-150$ & $68-70$ & $84-90$ & $84-90$ & $34-39$ \\
\hline INAA interval: & 77 & 31 & 61 & 130 & 50 & 35 & 105 & 65 & 33 & 84 & 127 & 65 & 65 & \\
\hline PGE interval: & $77-82$ & $31-35$ & $61-64$ & $130-138$ & $50-54$ & $33-42$ & $105-110$ & $75-84$ & $33-43$ & $88-110$ & $127-132$ & $65-74$ & $65-74 C$ & $27-31$ \\
\hline Unit: & 2 & 5 & 5 & 5 & 6 & 7 & 7 & 1 & 1 & 2 & $4 \mathrm{~A}$ & $4 B$ & 4B 1 & \\
\hline MUN \#: & M3278 & M3266 & M3271 & M3267 & M3270 & M3268 & M3277 & M3279 & M3275 & M3272 & M3269 & M3274 & M3273 & M3276 \\
\hline \multicolumn{15}{|c|}{ Major elements (wt\%): } \\
\hline $\mathrm{SiO}_{2}$ & 50.70 & 50.27 & 50.00 & & 50.63 & 49.87 & 49.53 & 50.39 & & 56.99 & 48.38 & 48.50 & & 53.28 \\
\hline $\mathrm{TiO}_{2}$ & 1.33 & 1.10 & 1.05 & & 1.41 & 1.20 & 1.19 & 1.14 & & 1.16 & 0.75 & 0.75 & & 0.65 \\
\hline $\mathrm{Al}_{2} \mathrm{O}^{3}$ & 16.24 & 17.04 & 17.20 & & 16.98 & 17.92 & 18.01 & 16.22 & & 14.48 & 16.59 & 16.28 & & 14.98 \\
\hline $\mathrm{Fe}_{2}^{2} \mathrm{O}^{3}$ & 10.12 & 9.22 & 8.90 & & 9.56 & 8.44 & 8.58 & 9.43 & & 12.43 & 9.29 & 9.37 & & 10.16 \\
\hline $\mathrm{MnO}$ & 0.13 & 0.15 & 0.13 & & 0.16 & 0.12 & 0.12 & 0.12 & & 0.23 & 0.15 & 0.15 & & 0.19 \\
\hline $\mathrm{MgO}$ & 7.19 & 8.50 & 8.99 & & 5.91 & 7.46 & 7.58 & 7.98 & & 3.53 & 7.98 & 9.52 & & 9.40 \\
\hline $\mathrm{CaO}$ & 11.04 & 11.66 & 11.54 & & 11.40 & 12.44 & 12.33 & 12.16 & & 8.06 & 14.46 & 13.06 & & 11.52 \\
\hline $\mathrm{Na}_{2} \mathrm{O}$ & 3.09 & 2.65 & 2.57 & & 3.31 & 2.52 & 2.67 & 2.11 & & 2.91 & 1.98 & 1.81 & & 1.37 \\
\hline $\mathrm{K}_{2} \mathrm{O}$ & 0.18 & 0.12 & 0.12 & & 0.31 & 0.02 & 0.04 & 0.12 & & 0.26 & 0.11 & 0.04 & & 0.30 \\
\hline $\mathrm{P}_{2} \mathrm{O}_{5}$ & 0.13 & 0.10 & 0.10 & & 0.21 & 0.11 & 0.11 & 0.11 & & 0.14 & 0.06 & 0.05 & & 0.07 \\
\hline Total & 100.15 & 100.81 & 100.60 & & 99.88 & 100.10 & 100.16 & 99.78 & & 100.19 & 99.75 & 99.53 & & 101.90 \\
\hline LOI & 2.22 & 1.70 & 3.36 & & 0.83 & 0.67 & 1.53 & 0.83 & & 0.78 & 2.06 & 1.49 & & \\
\hline \multicolumn{15}{|c|}{ Trace elements (ppm): } \\
\hline $\mathrm{Cr}$ & 41 & 148 & 191 & & 208 & 304 & 293 & 155 & & 9 & 342 & 293 & & 503 \\
\hline $\mathrm{Ni}$ & 40 & 90 & 91 & & 70 & 100 & 89 & 73 & & 8 & 103 & 113 & & 139 \\
\hline V & 266 & 183 & 189 & & 247 & 193 & 191 & 269 & & 402 & 234 & 221 & & 295 \\
\hline $\mathrm{Cu}$ & 74 & 75 & 82 & & 62 & 65 & 72 & 81 & & 135 & 114 & 110 & & 131 \\
\hline $\mathrm{Zn}$ & 57 & 42 & 38 & & 71 & 45 & 47 & 63 & & 102 & 35 & 57 & & 58 \\
\hline $\mathrm{Rb}$ & 1 & 1 & 1 & & 5 & 1 & 0 & 1 & & 4 & 7 & 1 & & 14 \\
\hline $\mathrm{Sr}$ & 187 & 183 & 170 & & 170 & 162 & 164 & 131 & & 138 & 356 & 143 & & 145 \\
\hline $\mathrm{Y}$ & 27 & 23 & 21 & & 36 & 25 & 25 & 22 & & 34 & 18 & 17 & & 15 \\
\hline $\mathrm{Zr}$ & 102 & 84 & 78 & & 119 & 93 & 98 & 45 & & 78 & 56 & 42 & & 30 \\
\hline $\mathrm{Nb}$ & 1 & 1 & 1 & & 2 & 1 & 1 & 1 & & 2 & 1 & nd & & 0 \\
\hline $\mathrm{Ba}$ & 49 & 50 & 49 & & 38 & 16 & 14 & 36 & & 89 & 11 & 21 & & 63 \\
\hline $\mathrm{Sc}$ & 39.1 & 34.3 & 36.0 & 37.1 & 31.7 & 31.4 & 33.6 & 38.7 & 35.0 & 37.0 & 44.2 & 45.4 & & 43.1 \\
\hline Co & 36.9 & 37.3 & 37.0 & 38.0 & 33.6 & 36.3 & 36.8 & 40.1 & 34.6 & 35.7 & 45.0 & 44.0 & & 42.3 \\
\hline $\mathrm{La}$ & 3.07 & 2.51 & 2.81 & 2.61 & 3.88 & 2.65 & 2.69 & 1.85 & 2.64 & 3.01 & 1.46 & 1.53 & & 1.55 \\
\hline $\mathrm{Ce}$ & 8.71 & 8.16 & 7.97 & 8.10 & 12.30 & 8.66 & 9.60 & 6.01 & 8.24 & 9.69 & 5.06 & 5.45 & & 8.63 \\
\hline Sm & 2.90 & 2.58 & 2.74 & 2.60 & 3.84 & 2.83 & 2.94 & 2.22 & 3.05 & 3.10 & 1.67 & 1.85 & & 1.59 \\
\hline Eu & 1.14 & 0.95 & 0.98 & 1.03 & 1.35 & 1.03 & 1.05 & 0.83 & 1.09 & 1.13 & 0.74 & 0.77 & & 0.62 \\
\hline $\mathrm{Tb}$ & 0.61 & 0.60 & 0.50 & 0.64 & 0.85 & 0.61 & 0.60 & 0.57 & 0.79 & 0.83 & 0.49 & 0.37 & & 0.34 \\
\hline $\mathrm{Yb}$ & 2.19 & 2.00 & 2.00 & 2.06 & 3.01 & 2.25 & 2.13 & 2.20 & 3.15 & 3.66 & 1.87 & 1.83 & & 1.56 \\
\hline Lu & 0.42 & 0.27 & 0.38 & 0.32 & 0.44 & 0.36 & 0.38 & 0.40 & 0.62 & 0.63 & 0.42 & 0.30 & & 0.24 \\
\hline $\mathrm{Hf}$ & 1.90 & 1.86 & 1.79 & 1.82 & 2.74 & 2.12 & 2.21 & 1.36 & 2.00 & 2.11 & 1.01 & 1.16 & & 0.78 \\
\hline $\mathrm{Ta}$ & 0.07 & $<0.07$ & 0.10 & $<0.07$ & 0.14 & 0.08 & 0.21 & $<0.07$ & 0.06 & 0.10 & $<0.07$ & $<0.08$ & & \\
\hline \multicolumn{15}{|c|}{ Noble metals (ppb): } \\
\hline $\mathrm{Rh}$ & 0.00 & 0.00 & 0.00 & 0.03 & 0.00 & 0.00 & 0.00 & 0.01 & 0.04 & 0.05 & 0.04 & 0.06 & 0.08 & 0.07 \\
\hline$P d$ & 0.26 & 1.15 & 0.80 & 0.88 & 2.26 & 0.26 & 0.20 & 0.41 & 2.47 & 3.40 & 3.83 & 3.75 & 4.37 & 2.72 \\
\hline Ir & 0.00 & 0.00 & 0.02 & 0.01 & 0.04 & 0.00 & 0.00 & 0.00 & 0.02 & 0.00 & 0.08 & 0.06 & 0.05 & 0.00 \\
\hline $\mathrm{Pt}$ & 0.02 & 0.61 & 0.85 & 1.41 & 0.34 & 0.40 & 0.30 & 0.24 & 1.57 & 2.38 & 1.12 & 1.77 & 2.2 & 1.69 \\
\hline $\mathrm{Au}$ & 1.98 & 2.12 & 1.88 & 7.10 & 9.96 & 4.84 & 1.03 & 2.44 & 7.92 & 5.22 & 11.37 & 10.02 & 5.15 & 6.82 \\
\hline
\end{tabular}

\section{DISCUSSION}

The noble metal concentrations and distributions for Leg 135 lavas appear to be primary, showing little or no effect of low-temperature alteration. Petrographic data for the analyzed samples range from fresh glass and holocrystalline basalt with low water contents (LOI $<1.00$ ) to basalts with the groundmass mesostasis variably altered to clays and with correspondingly higher water contents (LOI up to 3.36; see Table 1). Noble metal concentrations for the analyzed samples, however, show no correlation with any petrographic or geochemical alteration indices. Furthermore, the freshest samples (Hole 836A), which are composed of unaltered glass fragments, show the same geochemical signatures as more altered samples. For the purpose of the following discussion, we will assume that the analyzed values correspond with the primary abundances in the erupted magmas.

Comparison of Leg 135 noble metal values with major and trace element data suggest that low-pressure liquid fractionation processes were not significant in controlling the noble metal abundances of the samples. From shipboard descriptions, free sulfides were only observed in the Unit 5 diabase of Hole 834B, but Allan (pers. comm., 1992) notes that sulfide blebs were also present in at least Unit 7 at this site and in Unit 4 at Site 836. Gravitational separation of an immiscible sulfide phase could effectively remove noble metals from coexisting basaltic liquids; however, the Leg 135 rock units with observed sulfide blebs have similar noble metal contents to other units from the leg. Furthermore, sulfide separation will not fractionate the noble metals from each other because of the similar distribution coefficients (Kd's). Although we cannot rule out the possibility that the noble metal concentration differences between the two groups of lavas is a result of the previous separation of an immiscible sulfide liquid from the Site 834 and 835 magmas, no compelling data exists to indicate that this is the case. Indeed, the negative correlation of $\mathrm{Pt}$ and $\mathrm{Pd}$ with $\mathrm{Cu}$ at Sites 836 and 839 mitigates against a significant role for sulfides in these magmas. The overall lack of correlation of noble metal contents with low-pressure magmatic differentiation indices such as Mg\# (Fig. 3) and $\mathrm{Ni}$ and $\mathrm{Cr}$ contents suggests that the noble metal distributions observed are more likely related to mantle source processes rather than to liquid fractionation.

Within supra-subduction zone environments, potential source reservoirs for any erupting magma include variably depleted and enriched mantle, as well as components released from the downgoing slab into the overlying mantle-wedge. Evaluation of the relative contribution of each of these possible sources to Leg 135 volcanic rocks is compromised by the very limited data currently available on noble metal abundances in oceanic basalts (the products of mantle melting) as well as the composition of the subducting slab and the relative behavior of possible components released into the mantle-wedge. Table 2 compares the noble metal and $\mathrm{Cu}$ abundances and ratios of the two Leg 135 groups with the best available data for a variety of mantle melts, as well as MOR-sulfide data. It should be recognized 
Table 2. Comparison of average noble metal ( $\mathrm{ppb})$ and $\mathrm{Cu}$ abundances (ppm) from Leg 135 with oceanic basalts, boninites, komatities, and hydrothermal seafloor sulfide.

\begin{tabular}{|c|c|c|c|c|c|c|c|c|c|c|}
\hline & $\mathrm{Cu}$ & $\mathrm{Au}$ & $\mathrm{Rh}$ & $\mathrm{Pt}$ & $\mathrm{Ru}$ & Os & Ir & $\mathrm{Pd} / \mathrm{Ir}$ & $\mathrm{Au} / \mathrm{Pd}$ & $\mathrm{Au} / \mathrm{Ir}$ \\
\hline $834+835^{a}$ & 74 & 3.9 & 0.00 & 0.52 & - & - & 0.01 & 89 & 5.04 & 390 \\
\hline $836+839^{b}$ & 123 & 7.75 & 0.06 & 1.79 & - & - & 0.04 & 98 & 2.26 & 194 \\
\hline MORB $^{\mathrm{c}}$ & 72 & 0.69 & - & - & - & $\leq 0.013$ & $\leq 0.035$ & - & $\leq 1.0$ & $30^{k}$ \\
\hline Indian MORB ${ }^{d}$ & 115 & 3.5 & - & - & - & 0.08 & 0.12 & 48 & 0.61 & 30 \\
\hline Boninite $^{\circ}$ & 23 & 2.2 & - & - & - & - & 0.06 & 283 & 0.13 & 37 \\
\hline $\operatorname{Leg} 115^{f}$ & 147 & 3.2 & 0.31 & 7.3 & 0.22 & - & 0.11 & 74 & 0.4 & 29 \\
\hline Ocean Island tholeiite\& & - & 2.3 & - & - & - & - & 0.25 & 8.8 & 1.05 & 9.2 \\
\hline Ocean Island alk. & - & 0.50 & - & - & - & - & 0.30 & 5.0 & 0.33 & 1.67 \\
\hline Komatiites $^{i}$ & 69 & 2.4 & - & 8.2 & 5.8 & 2.4 & 1.9 & 4.8 & 0.26 & 1.26 \\
\hline MOR sulfidej & - & 38 & - & - & - & - & 0.01 & 250 & 599 & 150,000 \\
\hline
\end{tabular}

Notes:

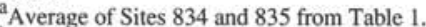

${ }^{\mathrm{b}}$ Average of Sites 836 and 839 from Table 1 .

${ }^{\mathrm{c}}$ Average of DSDP Leg 37, Hole 332B-12 (13 samples); Mid-Atlantic Ridge, Vema Fracture Zone (1 sample); Mid-Atlantic Ridge 22 ${ }^{\circ}$ S (1 sample); Mid-Atlantic Ridge, FAMOUS area (1 sample); South Atlantic, Bouvet Triple Junction (1 sample); South West Triple Junction, Indian Ocean (1 sample). Each sampling location given equal weight. Sources: Leg 37 ( $\mathrm{Au}, \mathrm{Pd}, \mathrm{Ir})=$ Crocket and Teruta (1977); all other data from Hertogen et al. (1980).

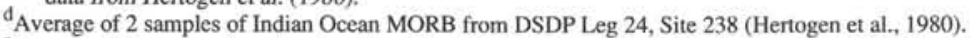

Average of 3 groups of modern boninites (Bonin Island, Cape Vogel, Mariana forearc, DSDP Site 458 = Hamlyn et al., 1985).

Composite average of ODP Leg 115 hotspot basalts (Greenough and Fryer, 1990).

$\mathrm{g}_{\mathrm{Au}}=$ average of 26 Hawaiian basalts (Gottried et al., 1972); Pd = average of data for 5 samples from Hawaii, Maui (Hawaii), James Island (Galapagos), Albermarle Island (Galapagos), and Réunion (Crocket and Skippen, 1966); $\mathrm{Ir}=$ average of 10 samples from Hawaii (Gottfried and Greenland, 1972).

${ }^{\mathrm{h}} \mathrm{Au}$ and $\mathrm{Ir}=$ average of 4 samples, Tahiti (Crocket et al., 1973); Pd = average of 4 samples from Tutuila (Samoa), Tahiti, St. Michael (Azores), and Ascension Island (Crocket and Skippen, 1966), 4 samples from Tahiti (Crocket et al., 1973).

'Composite average of 3 most primitive Gorgona, 3 most primitive Alex flow ( $\mathrm{Au}, \mathrm{Pd}, \mathrm{Ru}, \mathrm{Os}$, and $\mathrm{Ir}=\mathrm{Brugmann}$ et al., 1987 ), and 42 spinifex-textured komatiites from western Australia and Munro Township, Canada (Keays, 1982).

${ }^{\mathrm{j}}$ Single massive sulfide analysis, Middle Valley, northern Juan de Fuca Ridge (Crocket, 1990). Additional data: average Au and Ir abundances and $\mathrm{Au} / \mathrm{Ir}$ ratio for MORB sulfide globules are $19,000 \mathrm{ppb}, 1,200 \mathrm{ppb}$, and 16; massive sulfides from the Mid-Atlantic Ridge TAG area are $2,990 \mathrm{ppb}, 0.50 \mathrm{ppb}$, and 6,000 (Crocket, 1990).

${ }^{\mathrm{k}} \mathrm{Au} / \mathrm{Ir}$ ratio from Crocket (1990).

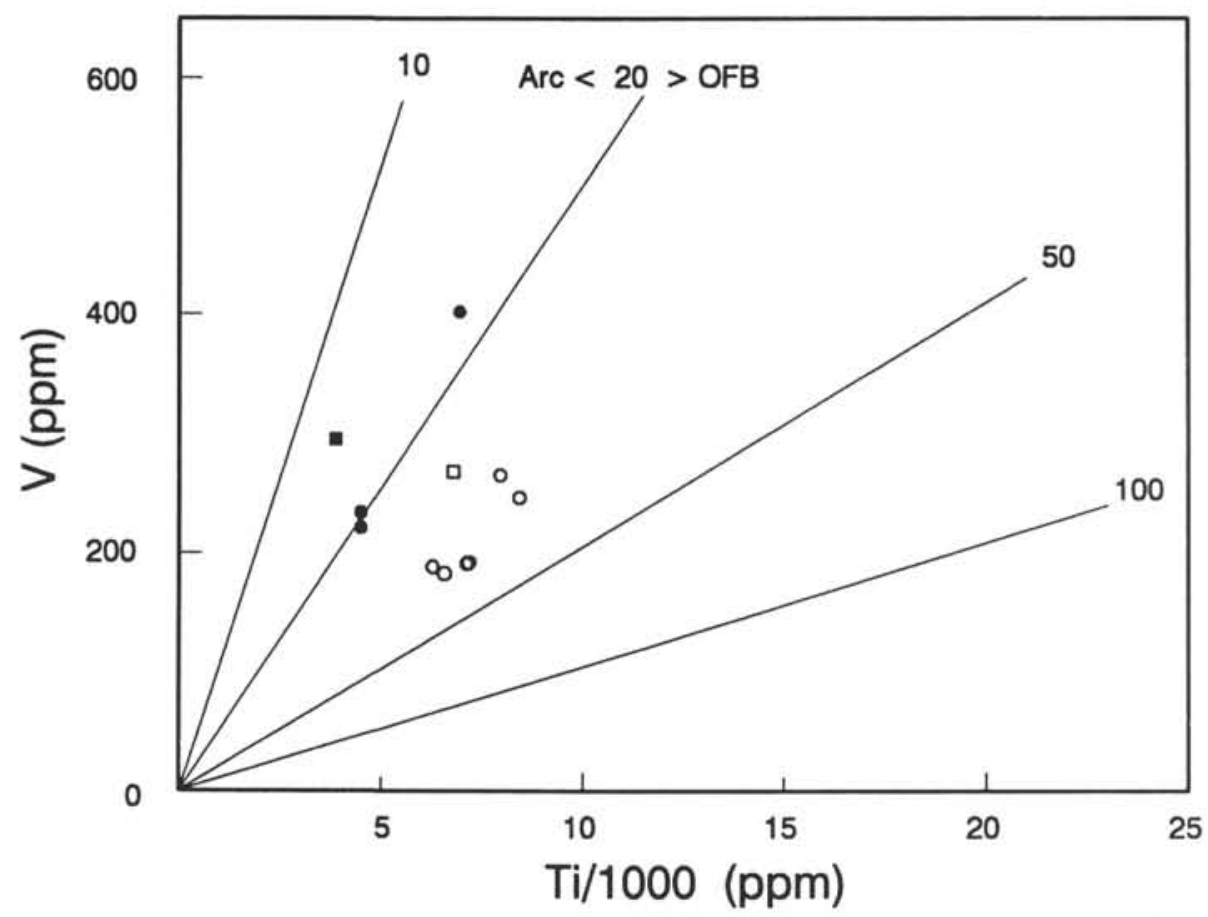

Figure 2. Plot of Ti vs. V for Leg 135 samples. Field for arc and ocean-floor basalts from Shervais (1982). Open circle $=$ Site 834, open square $=$ Site 835 , solid circle $=$ Site 836, solid square $=$ Site 839. For Samples 135-834B-13R-1 and 135-836A-3H-3, major and trace element values used in data analysis were taken from Samples 134-834B-12R-3 and 134-836A-3H-4, respectively, which on the basis of REE (Table 1) and other data are geochemically similar. Sample $135-836 \mathrm{~B}-5 \mathrm{R} 2-65-74 \mathrm{C}$ is a duplicate sample split of Sample $135-836 \mathrm{~B}-5 \mathrm{R}-2,65-74 \mathrm{~cm}$, and major and trace values from this latter sample were used in plotting the former. 

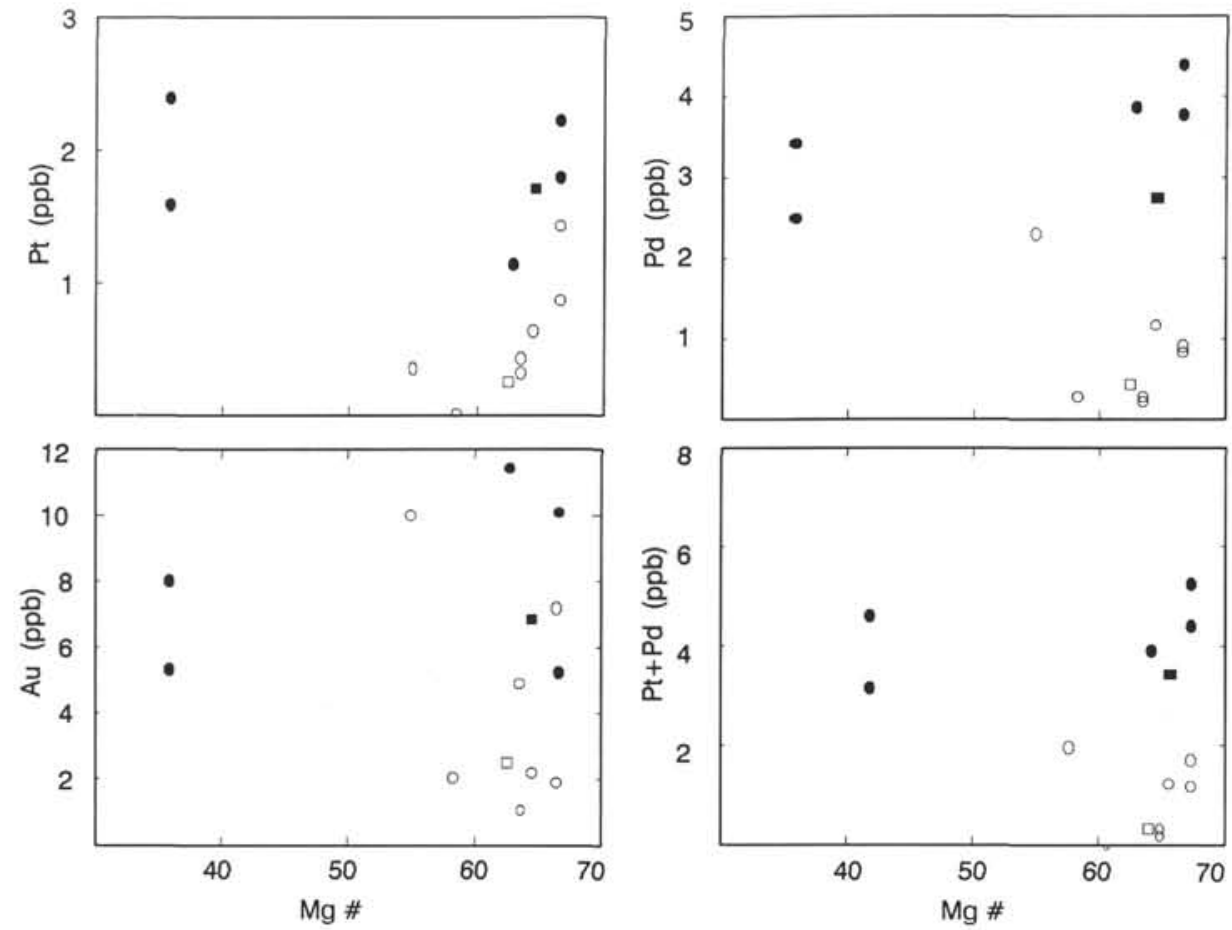

Figure 3. Plots of the noble metals Pt, Pd, Au, and Pd+Pt vs. Mg\# for Leg 135 lavas. Symbols are as in Figure 2.
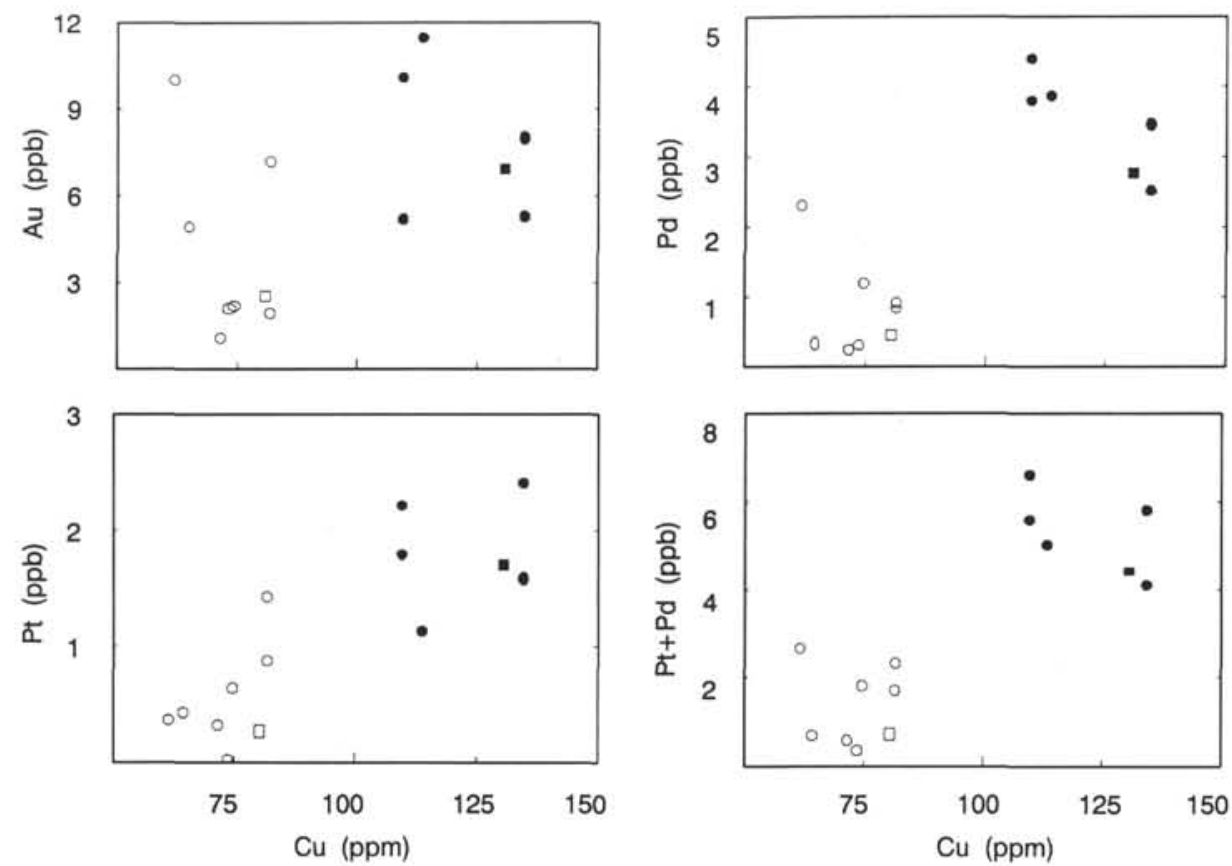

Figure 4. Plots of the noble metals Au, Pd, Pt, and Pd+Pt vs. Cu for Leg 135 lavas. Symbols are as in Figure 2.

that the comparative data is of variable quality and often is only available for a limited suite of the noble metals.

Figure 6 compares average Leg 135 data with selected igneous rock groups. The relatively strong fractionation of the Leg 135 PGE is similar to that observed in Leg 115 Indian Ocean hotspot basalts (Fig. 6A) and MORB (Fig. 6B). However, the distinctive enrichment of Au with respect to both $\mathrm{Cu}$ and $\mathrm{Pd}$ in Leg 135 volcanic rocks is not shown by other mantle melts such as MORB, ocean-island basalts, and komatiites, all of which have Au/Pd ratios $=1$ (Table 2 and Fig. 7). Anoma- lous primitive mantle-normalized Au values were observed in some supra-subduction zone settings (e.g., boninites; Fig. 6B), but these are depletions in gold relative to $\mathrm{Pd}(\mathrm{Au} / \mathrm{Pd}=0.13$; see Table 2$)$. The only potential source component for Leg 135 samples that is characterized by high $\mathrm{Au} / \mathrm{Pd}$ ratios is hydrothermal fluids and their derived precipitates (e.g., sediments and sulfides; Table 2 and Fig. 7). Gold concentrations in these precipitates are 2-3 orders of magnitude higher than for other oceanic crustal components. Even small additions of this component from the downgoing oceanic crust to the mantle melt zone 
A

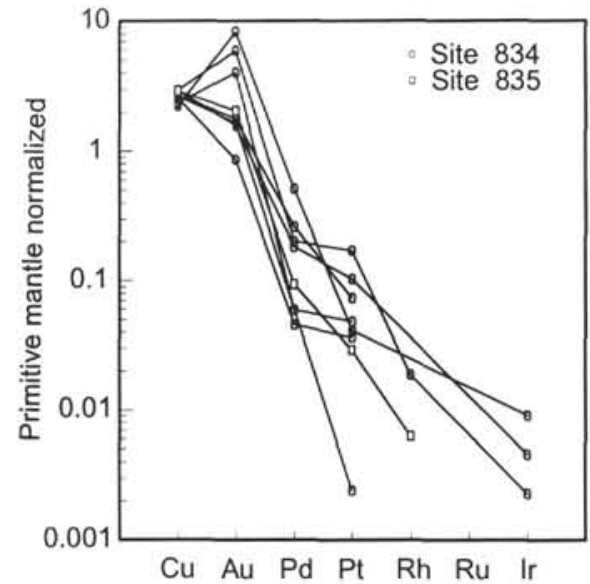

B

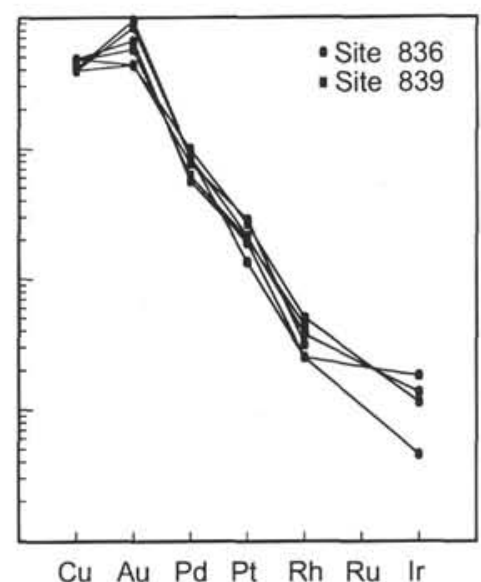

Figure 5. Primitive mantle normalized distribution patterns of $\mathrm{Cu}$, and the noble metals $\mathrm{Au}, \mathrm{Pd}$, $\mathrm{Pt}, \mathrm{Rh}, \mathrm{Ru}$, and $\mathrm{Ir}$ for Leg 135 Sites 834 and 835 (A) and Sites 836 and 839 (B). Mantle normalizing values for $\mathrm{Cu}(28 \mathrm{ppm})$ are from $\mathrm{Sun}(1982)$ and for $\mathrm{Au}, \mathrm{Pd}, \mathrm{Pt}, \mathrm{Rh}$, and $\operatorname{Ir}(1.2,4.4,8.3,1.6$, and $4.4 \mathrm{ppb}$ ) are 0.15 chondritic values as reported by Naldrett (1981) and summarized in Barnes et al. (1988). The order of elements has been reversed from normal to show increasing compatibility from left to right as is standard in petrogenetic studies.

A

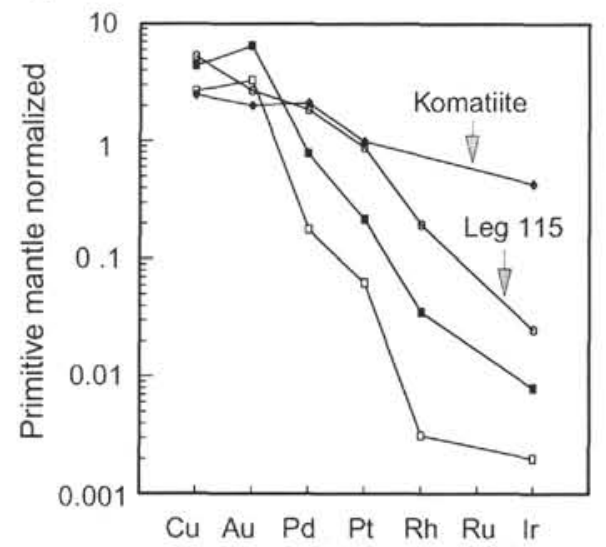

B

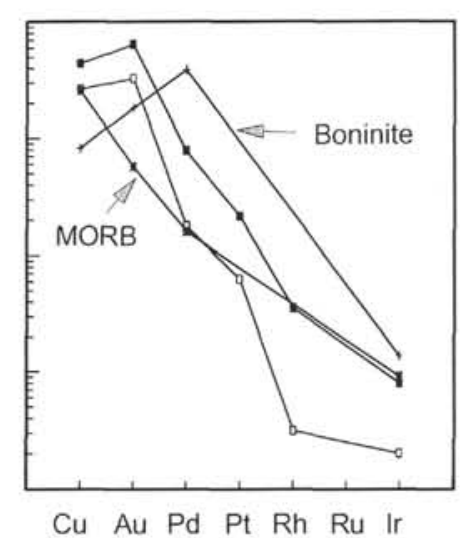

Figure 6. Primitive mantle normalized noble metal concentrations of Leg 135 lavas compared to average (A) komatiite and Leg 115 hotspot basalts, and (B) MORB and boninite. Data from Table 2. Open rectangle $=$ Sites 834 and 835 , and filled rectangle $=$ average of Sites 836 and 839 .

could account for the high mean $\mathrm{Au} / \mathrm{Pd}$ ratios of the Leg 135 samples (Sites 834 and 835, $\mathrm{Au} / \mathrm{Pd}=5.04$; Sites 836 and 839, $\mathrm{Au} / \mathrm{Pd}=2.26$ ).

Comparison of Leg 135 data with other supra-subduction zone rock types is limited to boninites, for which only $\mathrm{Au}, \mathrm{Pd}$, and Ir data are available (Hamlyn et al., 1985). Boninites are characterized by extreme PGE fractionation ( $\mathrm{Pd} / \mathrm{Ir}$ ratio $=280$; see Table 2 ) and strong depletion in both $\mathrm{Au}$ and $\mathrm{Cu}$ relative to $\mathrm{Pd}$ (Fig. 6). Recent suggestions that boninites represent melting of a young, hot subducted slab that lacked a sedimentary cover (J.A. Pearce, pers. comm., 1992) are consistent with our suggestion that the high $\mathrm{Au} / \mathrm{Pd}$ ratio of Leg 135 basalts reflects a sediment signature from the downgoing slab.

The high concentrations of gold and visible gold-bearing phases in sulfides from the Valu Fa Ridge (Eos, 1990; Herzig et al., in press) may be related to anomalous Au contents like those contained in the Leg 135 samples. Geochemical and isotopic analyses of Valu Fa lavas have previously established a strong slab-signature in their mantle source (Jenner et al., 1987; Vallier et al., 1991). However, Au concentrations of Lau Basin lavas are less than an order of magnitude greater than MORB, whereas Valu Fa hydrothermal precipitates are enriched by several orders of magnitude relative to any potential basaltic source, thereby indicating that source-rock composition alone cannot explain the presence of Au-bearing phases along the spreading ridge. Herzig et al. (in press) have suggested that efficient precipitation processes are crucial in ultimately determining the presence or absence of goldbearing hydrothermal phases from the Valu Fa Ridge.

\section{CONCLUSIONS}

Leg 135 backarc basin lavas are characterized by anomalously high Au contents and strongly fractionated relative PGE abundances. The Au signature may reflect separation of Au from the PGE within an oceanic hydrothermal system and subsequent release of this component to the mantle wedge during subduction of the downgoing slab. However, a detailed analysis of the relative contribution from other mantle sources (e.g., variably depleted or enriched mantle) to the Leg 135 magmas is limited by the lack of data on magmas derived from such sources. 


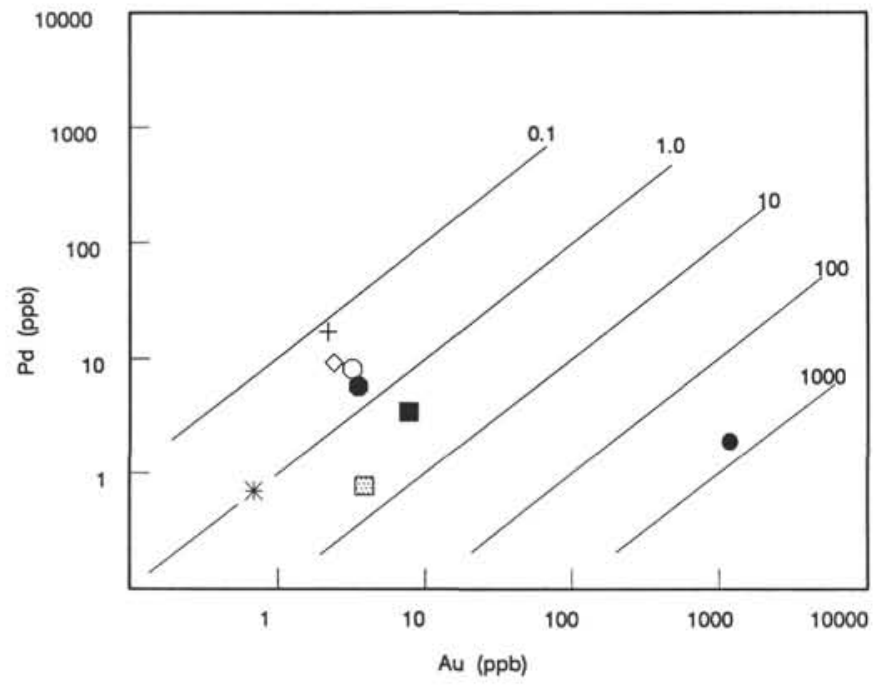

Figure 7. Plot of Pd vs. Au for Sites 834 and 835 (shaded square), Sites 836 and 839 (filled square), average MORB (asterisk), Leg 115 basalts (larger open circle), Indian Ocean MORB (filled circle), komatiite (open diamond), boninite (plus sign), and hydrothermal sulfide (smaller filled circle).

\section{ACKNOWLEDGMENTS}

We thank Jamie Allan for supplying samples for analysis as well as the major, trace, and REE data. Z. Chen, Bill Gosse, and Lakmal Hewa are thanked for assistance with noble metal analyses. NSERC operating grants to the authors helped defray the cost of this study. Jamie Allan, Mark Hannington, and Chris Lewis reviewed the manuscript.

\section{REFERENCES}

Agiorgitis, G., and Wolf, R., 1978. Aspects of osmium, ruthenium, and iridium contents in some Greek chromites. Chem. Geol., 23:267-272.

Barnes, S.-J., Boyd, R., Korneliussen, A., Nilsson, L.P., Often, M., Pedersen, R.B., and Robins, B., 1988. The use of mantle normalization and metal ratios in discriminating between the effects of partial melting, crystal fractionation, and sulphide segregation on platinum group elements, gold, nickel and copper: examples from Norway. In Prichard, H.M., Potts, P.J., Bowles, J.F.W., and Cribb, S.J. (Eds.), Geo-Platinum 87: Essex (Elsevier), 113-141.

Barnes, S.-J., and Naldrett, A.J., 1985. Geochemistry of the J-M (Howland) reef of the Stillwater Complex, Minneapolis Adit area. I. Sulfide chemistry and sulfide-olivine equilibrium. Econ. Geol., 80:627-645.

Brugmann, G.E., Arndt, N.T., Hofmann, A.W., and Tobschall, H.J., 1987. Noble metal abundances in komatiite suites from Alexo, Ontario, and Gorgona Island, Columbia. Geochim. Cosmochim. Acta, 51:2159-2169.

Bush, S.M., 1990. Gold found in Lau back-arc sulfides. Eos, 71:1083, 1090.

Crocket, J.H., 1981. Geochemistry of the platinum group elements. In Cabri, L.J. (Ed.), Platinum Group Elements: Mineralogy, Geology, Recovery. CIM, Spec. Vol., 23:47-64.

, 1990. Noble metals in seafloor hydrothermal mineralization from the Juan de Fuca and Mid-Atlantic ridges: a fractionation of gold from platinum metals in hydrothermal fluids. Can. Mineral., 28:639-648.

Crocket, J.H., Macdougall, J.D., and Harris, R.C., 1973. Gold, palladium and iridium in marine sediments. Geochim. Cosmochim. Acta, 37:2547-2556.

Crocket, J.H., and Shippen, G.B., 1966. Radioactivation determination of palladium in basaltic and ultrabasic rocks. Geochim. Cosmochim. Acta, 30:129-141.

Crocket, J.H., and Teruta, Y., 1977. Palladium, iridium, and gold contents of mafic and ultramafic rocks drilled from the Mid-Atlantic Ridge, Leg 37, Deep Sea Drilling Project. Can. J. Earth Sci., 14:777-784.

Fouquet, Y., von Stackelberg, U., Charlou, J.L., Donval, J.P., Foucher, J.P., Erzinger, J., Herzig, P., Muhe, R., Wiedicke, M., Soakai, S., Whitechurch,

\footnotetext{
Abbreviations for names of organizations and publication titles in ODP reference lists follow the style given in Chemical Abstracts Service Source Index (published by American Chemical Society).
}

H., 1991. Hydrothermal activity in the Lau back-arc basin: sulfides and water chemistry. Geology, 19:303-306.

Fouquet, Y., von Stackelberg, U., and Shipboard Scientific Party, 1990. Hydrothermal activity in the Lau Basin: first results from the NAUTILAU cruise. Eos, 71:678-679.

Frenzel, G., Mühe, R., Stoffers, P., 1990. Petrology of volcanic rocks from the Lau Basin, Southwest Pacific. Geol. Jahrb., 92:395-479.

Fryer, B.J., and Greenough, J.D., in press. Evidence for mantle heterogeneity from PGE abundances in Indian Ocean basalts. Can. J. Earth Sci.

Gottried, D., and Greenland, L.P., 1972. Variation of iridium and gold in oceanic and continental basalts. 24th Int. Geol. Congr., Rep. Sess., Sect. 10:135-144.

Gottfried, D., Rowe, J.J., and Tilling, R.I., 1972. Distribution of gold in igneous rocks. Geol. Surv. Prof. Pap. U.S., 727.

Greenough, J.D., and Fryer, B.J., 1990. Distribution of gold, palladium, platinum, rhodium, ruthenium, and iridium in Leg 115 hotspot basalts: implications for magmatic processes. In Duncan, R.A., Backman, J., Peterson, L.C., et al., Proc. ODP, Sci. Results, 115: College Station, TX (Ocean Drilling Program), 71-84.

Hamlyn, P.R., Keays, R.R., Cameron, W.E., Crawford, A.J., and Waldron, H.M., 1985. Precious metals in magnesian low-Ti lavas: implications for metallogenesis and sulfur saturation in primary magmas. Geochim. Cosmochim. Acta, 49:1797-1811.

Hawkins, J.W., and Melchior, J.T., 1985. Petrology of Mariana Trough and Lau Basin basalts. J. Geophys. Res., 90:11431-11468.

Hertogen, J., Janssens, M.-J., and Palme, H., 1980. Trace elements in ocean ridge basalt glasses: implications for fractionations during mantle evolution and petrogenesis. Geochim. Cosmochim. Acta., 44:2125-2143.

Herzig, P.M., Hannington, M.D., Fouquet, Y., von Stackelberg, U., and Peterson, S., in press. Gold-rich polymetallic sulfides from the Lau back-arc and implications for the geochemistry of gold in seafloor hydrothermal systems of the S.W. Pacific. Econ Geol.

Jackson, S.E., Fryer, B.J., Gosse, W., Healey, D.C., Longerich, H.P., and Strong, D.F., 1990. Determination of the precious metals in geological materials by inductively coupled plasma-mass spectrometry (ICP-MS) with nickel sulphide fire-assay collection and tellurium coprecipitation. Chem. Geol., 83:119-132.

Jenner, G.A., Cawood, P.A., Rautenschlein, M., and White, W.M., 1987. Composition of back-arc basin volcanics, Valu Fa Ridge, Lau Basin: evidence for a slab-derived component in their mantle source. J. Volcanol. Geotherm. Res., 32:209-222.

Karig, D.E., 1970. Ridges and basins of the Tonga-Kermadec island arc system. J. Geophys. Res., 75:239-254.

Keays, R.R., 1982. Palladium and iridium in komatiites and associated rocks: application to petrogenetic problems. In Arndt, N.T., and Nisbett, E.G. (Eds.), Komatiites: London (Allen \& Unwin), 435-457.

Keays, R.R., and Crocket, J.H., 1970. A study of precious metals in the Sudbury nickel irruptive ores. Econ. Geol., 65:438-450.

Naldrett, A.J., 1981. Platinum-group element deposits. In Cabri, L.J. (Ed.), Platinum Group Elements: Mineralogy, Geology, Recovery. CIM, Spec. Vol., 23:197-231.

Naldrett, A.J., Hoffman, E.L., Green, A.H., Chou, C.-L., Naldrett, S.R., and Alcock, R.A., 1979. The composition of Ni-sulphide ores, with particular reference to their content of PGE and Au. Can. Mineral., 17:403-415.

Parson, L., Hawkins, J., Allan, J., et al., 1992. Proc. ODP, Init. Repts., 135: College Station, TX (Ocean Drilling Program).

Shervais, J.W., 1982. Ti-V plots and the petrogenesis of modern and ophiolitic lavas. Earth Planet. Sci. Lett., 59:101-118.

Stockman, H.W., and Hlava, P.F., 1984. Platinum-group minerals in Alpine chromitites from southwestern Oregon. Econ. Geol., 79:491-508.

Sun, S.-S., 1982. Chemical composition and origin of the Earth's primitive mantle. Geochem. Cosmochim. Acta, 46:179-192.

Vallier, T.L., Jenner, G.A., Frey, F., Gill, J., Davis, A.S., Hawkins, J.W., Morris, J.D., Cawood, P.A., Morton, J., Scholl, D., Rautenschlein, M., White, W.M., Williams, R.W., Volpe, A.M., Stevenson, A.J., and White, L.D., 1991. Subalkaline andesite from Valu Fa Ridge, a back arc spreading center in southern Lau Basin: petrogenesis, comparative chemistry, and tectonic implication. Chem. Geol., 91:227-256.

Volpe, A.M., Macdougall, J.D., and Hawkins, J.W., 1988. Lau basin: trace element and $\mathrm{Sr}-\mathrm{Nd}$ isotopic evidence for heterogeneity in backarc basin mantle. Earth Planet. Sci. Lett., 90:174-186.

Date of initial receipt: 15 June 1992

Date of acceptance: 1 March 1993

Ms 135SR-137 